\title{
Mitochondrial DNA variation in wild populations of Leporinus elongatus from the Paraná River basin
}

\author{
Cesar Martins, Adriane P. Wasko, Claudio Oliveira and Fausto Foresti \\ Departamento de Morfologia, Instituto de Biociências, Universidade Estadual Paulista, \\ Botucatu, SP, Brazil.
}

\begin{abstract}
Leporinus elongatus, a fish species widely distributed throughout the Paraná River basin in South America, is an important fishery resource and a valuable species in aquaculture programs. Despite its great economic importance, several wild populations have been suffering a drastic reduction. The comprehension of its population structure represents an important step for the conservation of these organisms in natural environments, and also for the selection of wild stocks to be used in hatchery programs. In order to understand the genetic-population structure of $L$. elongatus, D-loop mitochondrial DNA analyses were applied in six wild populations of the species. The results were used to estimate the levels of within and among population genetic variability. Although the D-loop variations could not be correlated to the geographic distribution of these organisms, it was possible to detect high levels of genetic variability within each population and the occurrence of exclusive population haplotypes, which suggests a partial genetic differentiation among them. The obtained data can be useful in selecting fish stocks that preserve a better genetic diversity of $L$. elongatus for use in conservation and/or hatchery programs.
\end{abstract}

Key-words: conservation genetics, D-loop, genetic variability, Leporinus elongatus, mtDNA.

Received: May 6, 2002; accepted: January 27, 2003.

\section{Introduction}

The Anostomidae family (Characiformes), comprised of twelve genera thus far recognized, is an important freshwater fish group distributed throughout the Neotropical region (Géry, 1977). Leporinus, the most diversified genera of Anostomidae, is distributed from Central to South America and several species, such as $L$. macrocephalus, L. obtusidens and L. elongatus, represent important fishery resources for many South American communities. Despite the great economic importance of $L$. elongatus (piapara), a migratory species widely distributed throughout the Paraná River basin, a decrease in the amount of collected individuals in the last years has been reported (fishermen of Guaíra, Paraná State, Brazil, personal communication), probably due to habitat alterations. Surprisingly, no information is available on the genetic diversity of natural populations of this species, even though such data may be critical to their survival and conservation. Since $L$. elongatus represents an endangered fishery resource and a promising species to be cultivated in fish farms, the careful selection of appropriate wild stocks, based on genetic crite-

Send correspondence to C. Martins. Departamento de Morfologia, Instituto de Biociências, Universidade Estadual Paulista, 18618-000, Botucatu, SP, Brazil. E-mail: cmartins@ibb.unesp.br. ria, can offer greater potential for success in species-recovery and maintenance programs and support for aquaculture activities in order to increase fish production.

In recent years, different molecular techniques, using nuclear or mitochondrial DNA (mtDNA), have provided new information concerning the genetic variability of wild and cultivated populations of several fish species (Bielawski and Pumo, 1997; Nielsen et al., 1995; Perez-Enriquez et al., 1999; Koh et al., 1999; Iguchi et al., 1999; Reilly et al., 1999; Sivasundar et al., 2001; Yoon and Park, 2002; Was and Wenne, 2002; among others), permitting the delineation of management units and allowing assessment of conservation priorities. The mitochondrial DNA can be an efficient tool for gathering information for population genetic analyses since it has unique characteristics due to its maternal transmission, rapid rate of evolutionary changes, transmission without recombination, and haploid inheritance (Avise, 1994). Therefore, mtDNA variations can be extremely useful for identifying and managing stocks of fish species (Grewe and Hebert, 1988; Billington et al., 1992).

To date, there has been no literature on genetic stock characterization of Leporinus elongatus populations. Focusing on the genetic diversity of natural populations of $L$. elongatus, the aim of the present study was to present a pre- 
liminary assessment of the genetic variability of six wild populations, based in the nucleotide sequence of a segment of the non-coding control region (D-loop) of the mitochondrial genome. The results were useful not only to characterize L. elongatus, but also to give support to recovery efforts and to the biodiversity maintenance of this fish species.

\section{Material and Methods}

\section{Sample collection and DNA extraction}

Specimens of Leporinus elongatus were obtained from six wild populations from the Paraná River basin (Figure 1 and Table 1). In order to compare to the results of $L$. elongatus, another four Anostomidae fish species (Leporinus cf. elongatus, Leporinus obtusidens, Leporinus friderici and Leporinus desmotes) and one Parodontidae species (Parodon tortuosus) were also analyzed. Total genomic DNA was obtained from fish caudal or anal fin tissue samples, in order to prevent the sacrifice of the animals, using a TNES-urea-digestion buffer $(10 \mathrm{mM}$ Tris- $\mathrm{HCl} \mathrm{pH}$ $8.0 ; 125 \mathrm{mM} \mathrm{NaCl} ; 10 \mathrm{mM}$ EDTA pH 8.0; 0.5\%SDS; $4 \mathrm{M}$ urea), according to A.P. Wasko, C.A. Martins, C. Oliveira and F. Foresti (unpublished data). Further DNA purification was performed with phenol-chloroform (Sambrook and Russell, 2001).

\section{PCR amplification of the D-loop region of the mtDNA}

A segment of approximately 1.300 base pairs (bp) that corresponds to the D-loop region of the mtDNA was amplified by PCR using the primers Dloop2F (5' - GCC TAA GAG CAT CGG TCT TGT AA - 3') and Dloop2R (5' - GTC AGG ACC ATG CCT TTG TG - 3') (R.A. Torres, personal communication). Amplifications were carried out using $0.4 \mathrm{mM}$ of each primer, $100 \mathrm{ng}$ of total genomic DNA, 1x Taq buffer, $200 \mu \mathrm{M}$ of each dNTP and 2U of Taq DNA polymerase in a final reaction volume of $50 \mu \mathrm{L}$. Cycling times were as follow: $94{ }^{\circ} \mathrm{C}(5 \mathrm{~min})$ of denaturation, 35 cycles of $1 \mathrm{~min}$ at $92{ }^{\circ} \mathrm{C}, 1 \mathrm{~min}$ at $50{ }^{\circ} \mathrm{C}$ and $1.5 \mathrm{~min}$ at $70{ }^{\circ} \mathrm{C}$. A final 7-minute extension step was done at $72{ }^{\circ} \mathrm{C}$. The PCR-amplified products were analyzed in $1 \%$ agarose gels in 1x TAE buffer (Tris-Acetic acid-EDTA). Amplified

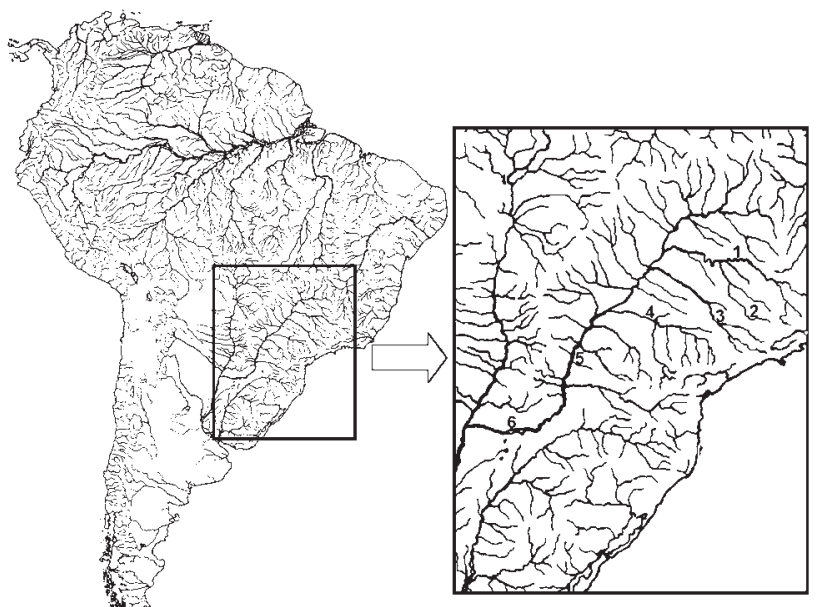

Figure 1 - South America geographic map indicating sampling localities of Leporinus elongatus from the Paraná River basin. (1) Grande River, (2) Mogi-Guaçu River, (3) Piracicaba/Tietê Rivers, (4) Paranapanema River, (5) Paraná River, Municipality of Guaíra, and (6) Paraná River, Municipality of Ayolas. (1-5) Brazil, (6) Paraguay.

fragments were visualized with Ethidium Bromide staining (Sambrook and Russell, 2001) under UV illumination and recorded with the Kodak Digital Science 1D computer program. Molecular weights were estimated using a standard DNA marker.

\section{DNA sequencing and D-loop sequence analyses}

PCR fragments were purified using the $\mathrm{GFX}^{\mathrm{TM}}$ PCR DNA kand Gel Band Purification (Amersham Pharmacia Biotech) kit and sequenced on the OpenGene Automated DNA Sequencing System I (Visible Genetics Inc.) with a Thermo Sequenase Cy 5.5 Terminator Cycle Sequencing kit (Amersham Pharmacia Biotech). Nucleic acid sequences were subjected to BLASTn (Altschul et al., 1990) searches at the National Center for Biotechnology Information (NCBI), website (http://www.ncbi.nlm.nih.gov/blast) and they were aligned using ClustalW software (Thompson et al., 1994), web site (http://www.ebi.ac.uk/clustalw/). Sequences of the mtDNA control region of Leporinus elongatus were deposited in GenBank, under the accession

Table 1 - Leporinus elongatus collection localities and sample sizes from the Paraná River basin.

Brazil

1 Grande River, Municipality of São José da Barra, Minas Gerais State

2 Mogi-Guaçu River, Municipality of Pirassununga, São Paulo State

3 Paranapanema River, Municipality of Salto Grande, São Paulo State

4 Piracicaba River and Tietê River, Municipality of Santa Maria da Serra, São Paulo State

5 Paraná River, Municipality of Guaíra, Paraná State 
numbers AY100330-AY100372. Kimura 2-parameter genetic distances (Kimura, 1980) were determined using the computer program Molecular Evolutionary Genetics Analysis (MEGA Version 2.1). The number of haplotypes, haplotype diversity, and nucleotide diversity were calculated using the program DNA SP version 3.0 (Rozas and Rozas, 1999).

\section{Results and Discussion}

Previous studies have shown that the D-loop region, i.e. a non-coding control region of the mtDNA, corresponds to a DNA segment with rapid evolution in the mitochondrial genome (Saccone et al., 1993). Although the main domain of this region exhibits a great nucleotide similarity among different species and presents a divergence index similar to the one observed in the mitochondrial genes that code for proteins, the peripheral regions that flank the main domain present a rapid level of evolution, which generates size and base composition heterogeneity (Sbisà et al., 1997). Therefore, in the present study, we intended to analyze the nucleotide sequence of one of the peripheral domains of the D-loop region of Leporinus elongatus in order to achieve a preliminary assessment of the genetic variability in wild populations of the species.

The PCR amplification of the total genomic DNA of several individuals of Leporinus elongatus, using primers D-loop2F e D-loop2R, generated a fragment of approximately 1.300 base pairs (bp) that corresponds to the mtDNA D-loop region (Figure 2). No size or heteroplasmy polymorphism was observed within or among individuals from the six sampled L. elongatus populations. However, distinct amplified D-loop size-fragments were detected in different Leporinus species, which permitted the identification of a possible species-specific mtDNA band patterns for some species of the genus, such as $L$. obtusidens and $L$. desmotes (Figure 2). A D-loop fragment of approximately $1.300 \mathrm{bp}$ could also be identified for Parodon tortuosus (Figure 2), a fish species closely related to the Anostomidae group.

After purifying the $1.300 \mathrm{bp}$-amplified DNA fragment from agarose gels, the D-loop fragments of several $L$.

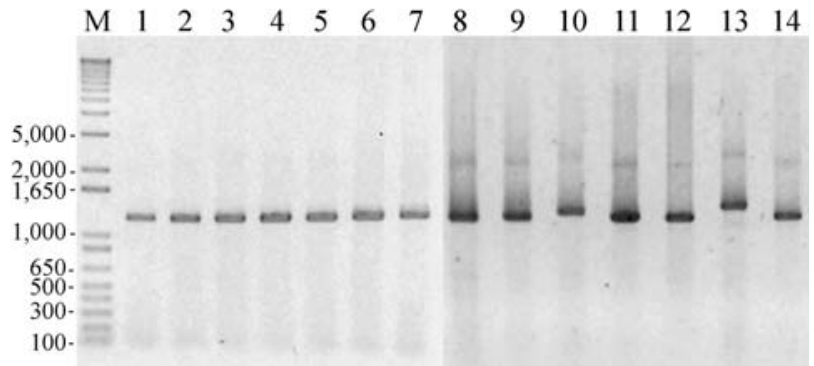

Figure 2 - 1\% agarose gel of PCR-generated D-loop mtDNA fragments of Leporinus elongatus (1-8), Leporinus cf. elongatus (9), Leporinus obtusidens (10), Leporinus friderici (11-12), Leporinus desmotes (13), and Parodon tortuosus (14). M indicates $1 \mathrm{~Kb}$ ladder for molecular weight markers. elongatus individual were sequenced using the primer D-loop2F. A D-loop segment of approximately 300 base pairs, flanked by the proline RNAt gene, was obtained for 43 individuals of the species sampled from the Grande River, Mogi-Guaçu River, Piracicaba/Tietê Rivers, Paranapanema River, and Paraná River populations (Table 1).

At present, all the analyzed organisms, except primates, show an AT-content higher than the GC-content in the entire D-loop region. In primates, the AT-rich regions can be identified in the peripheral domains of the $\mathrm{D}$-loop region, while the GC-content is higher in the main domain (Sbisà et al., 1997). The fish species Leporinus elongatus also presented a higher proportion of AT nucleotides in the D-loop mtDNA. The obtained D-loop nucleotide sequences of the sampled individuals of the species were $70.20 \%$ AT-rich and $29.80 \%$ GC-rich. Moreover, the amount of nucleotide bases of the D-loop region of $L$. elongatus followed the rule $\mathrm{A}>\mathrm{T}>\mathrm{C}>\mathrm{G}$, that also seems to be a common feature in the peripheral domains of the light-strand of the D-loop region of distinct organisms (Sbisà et al., 1997).

The L. elongatus mtDNA sequences presented 198 variable sites (63.46\%) and 109 conserved sites (34.93\%). The conserved positions were observed at a higher frequency in the initial portion of the nucleotide sequence (nucleotides 1 to $+/-170$ ) and the variable regions were mostly visualized between nucleotides 170 and 312 . Figure 3 presents the nucleotide sequence alignment of the observed variable sites of the 43 analyzed $L$. elongatus individuals sampled from distinct populations. Although a few base substitutions were identified in the D-loop sequences of the species, short insertions/deletions were more frequent. Similarly, the occurrence of short base insertions and deletions has been observed in the mtDNA sequences of other fish, such as salmonid species (Shedlock et al., 1992). Traces of imperfect tandem repeats were also observed in the L. elongatus D-loop sequences. These tandem repeats, typically found in the 5'-end or in the 3'-end of the D-loop segment, where the DNA replication initiates and ends, respectively (Lee et al., 1995; Nesbo et al., 1999), can be correlated to intra and inter-individual size variations in the D-loop region (Brzuzan, 2000).

Results of the inferences of the Kimura 2-parameter genetic distances (Kimura, 1980), based on nucleotide divergence, showed that the nucleotide divergence values varied from 0.000 (distance between identical nucleotide sequences) to 0.165 , with an average value equal to 0.037 . The average within and among population genetic distance values for $L$ elongatus were also obtained (Table 2 ). The population from the Paraná River-Guaíra showed the lowest genetic distance index (average value of 0.016) in relation to the other sampled locations, indicating a higher genetic similarity among the individuals of this region. The Paranapanema River and the Paraná River-Ayolas popula- 


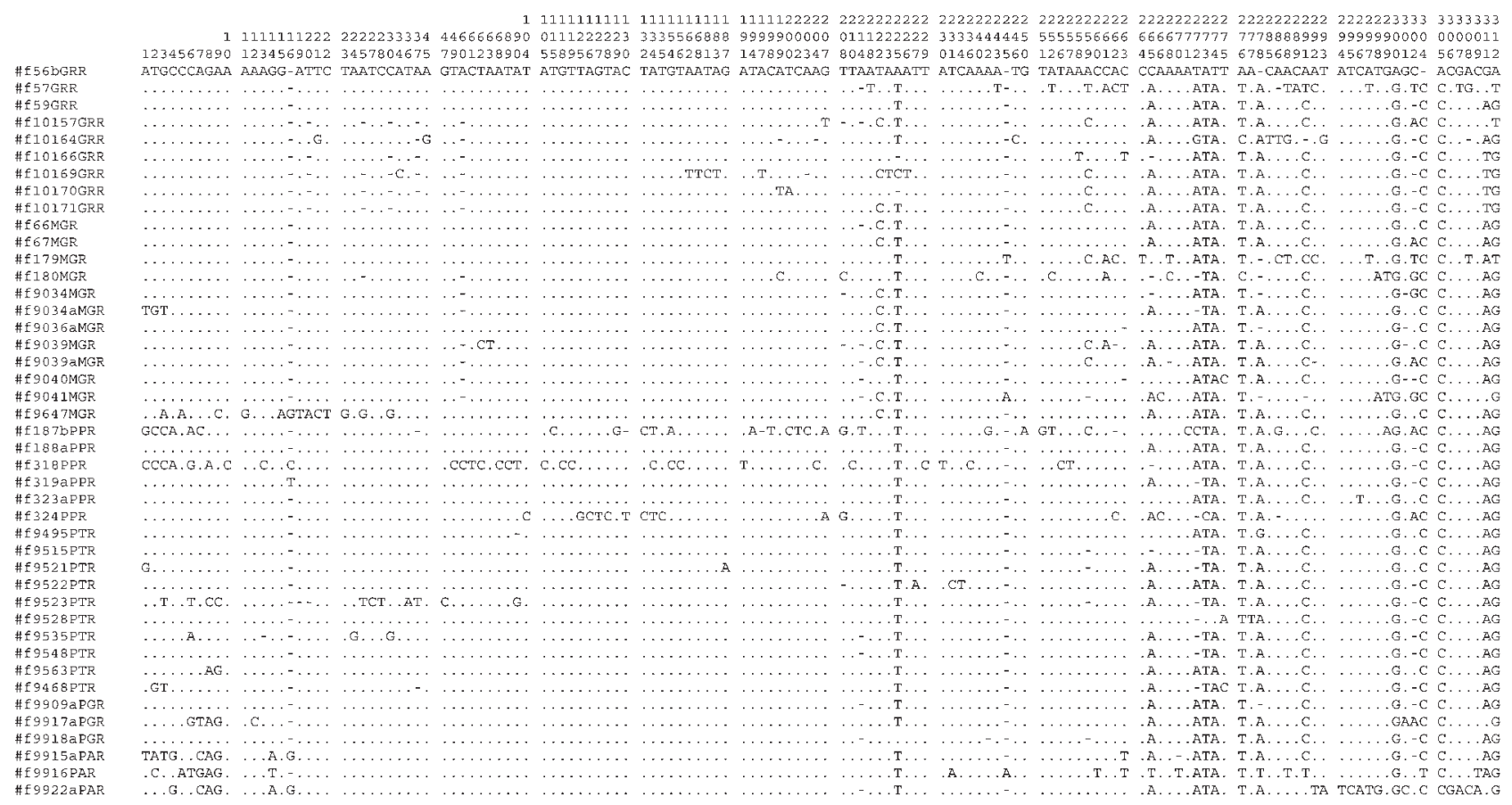

Figure 3 - Nucleotide sequence alignment of the observed variable sites in the D-loop 5'-region of 43 Leporinus elongatus individuals sampled from distinct populations from Grande River (GRR), Mogi-Guaçu River (MGR), Paranapanema River (PPR), Piracicaba/Tietê Rivers (PTR), Paraná RiverGuaíra (PGR), and Paraná River-Ayolas (PAR). Hyphens indicate gaps and dots represent nucleotide identity.

Table 2 - Nucleotide diversity among sampled populations of $L$. elongatus (above the diagonal, columns 1-6) and average genetic distances, based on nucleotide divergence, within (column 7) and among distinct populations of L. elongatus (below the diagonal).

\begin{tabular}{lccccccc}
\hline Sampled populations & 1 & 2 & 3 & 4 & 5 & 6 & 7 \\
\hline Grande River & - & 0.050 & 0.058 & 0.049 & 0.050 & 0.078 & 0.034 \\
Mogi-Guaçu River & 0.029 & - & 0.044 & 0.020 & 0.020 & 0.041 & 0.021 \\
Paranapanema River & 0.060 & 0.053 & - & 0.027 & 0.027 & 0.052 & 0.077 \\
Piracicaba/Tietê Rivers & 0.029 & 0.022 & 0.049 & - & 0.019 & 0.056 & 0.019 \\
Paraná River-Guaíra & 0.026 & 0.021 & 0.047 & 0.017 & - & 0.045 & 0.016 \\
Paraná River-Ayolas & 0.064 & 0.057 & 0.082 & 0.052 & 0.046 & - & 0.060 \\
\hline
\end{tabular}

tions showed a greater genetic variability since higher genetic distance indices $(0.077$ and 0.060 , respectively) were obtained for the sampled individuals from these regions. Based on the obtained D-loop nucleotide divergence indices, it was also possible to infer that the Leporinus elongatus populations from the Paraná River-Guaíra and from the Piracicaba/Tietê Rivers presented a higher genetic similarity, while the individuals sampled at the Paraná River-Ayolas represented the most divergent population of the species, since they presented higher genetic distance indices compared to the other analyzed populations (Table 2). A D-loop nucleotide sequence of another fish species, Prochilodus lineatus (Sivasundar et al., 2001), was also included in the genetic distance analysis and, as expected, it presented a lower genetic similarity with all the sampled $L$. elongatus populations, with an average nucleotide diversity of 0.540 .
A total of 32 distinct D-loop mtDNA haplotypes could be identified in the six sampled populations of $L$. elongatus (Table 3). A common haplotype was not observed in any the populations of the species and several haplotypes could be considered exclusive to a specific population, suggesting a reduced gene flow among them. Differences in the haplotype number and frequency led to a high haplotype diversity that ranged from 0.848 to 1.000 , with an average value equal to 0.958 (Table 3 ). The elevated nucleotide diversity observed in $L$. elongatus also reflected high levels of haplotype diversity. The percentage of nucleotide diversity ranged from 1.78 in the samples from the Piracicaba/Tietê Rivers to 7.70 in the Paranapanema River (Table 3).

Although the obtained data proved ineffective in separating the sampled Leporinus elongatus populations into distinct groups, it was possible to detect high levels of ge- 
Table 3 - Sample sizes, number of D-loop mtDNA haplotypes, haplotype diversity, and nucleotide diversity, obtained for the sampled populations of Leporinus elongatus.

\begin{tabular}{lcccc}
\hline Sampled populations & Sample sizes & Number of haplotypes & Haplotype diversity & Nucleotide diversity (\%) \\
\hline Grande River & 09 & 09 & 1.000 & 3.83 \\
Mogi-Guaçu River & 12 & 08 & 0.848 & 2.21 \\
Paranapanema River & 06 & 05 & 0.933 & 7.70 \\
Piracicaba/Tietê Rivers & 10 & 09 & 0.978 & 1.78 \\
Paraná River-Guaíra & 03 & 03 & 1.000 & 1.82 \\
Paraná River-Ayolas & 03 & 03 & 1.000 & 3.73 \\
Total & 43 & 32 & 0.958 & 3.51 \\
\hline
\end{tabular}

netic variability within each population and the occurrence of exclusive population haplotypes, which suggest a partial genetic differentiation among the analyzed populations. High levels of genetic variability in the D-loop nucleotide sequence have been commonly identified in wild populations of other fish species (Igushi et al., 1999). Therefore, the analysis of mtDNA haplotypes represents an important tool for the characterization of distinct populations, for the evaluation of the genetic variability, and for the identification of genetic markers, which could be extremely useful in conservation and hatchery programs of fish species.

Despite the great economic importance of Leporinus elongatus as a fishery resource and a valuable species in aquaculture programs, several wild populations of the species have been suffering a drastic reduction in the last years. The careful selection of appropriate natural stocks, based on genetic criteria, can offer greater potential for success in species-recovery and maintenance programs (Quattro and Vrijenhoek, 1989), and the present data on the L. elongatus mitochondrial D-loop could be extremely useful to choose founder wild stocks of the species that retain more DNA variability. Moreover, it would be instructional to continue the genetic characterization and monitoring of natural and captive stocks of the species in coming years, using other molecular markers such as RAPD and microsatellites, since further genetic data results will be of great value to establish a clear scene of the distribution and dynamics of the Leporinus elongatus populations in the Paraná River basin.

\section{Acknowledgements}

C.M and A.P.W. were supported by fellowships from Fundação de Amparo à Pesquisa do Estado de São Paulo (FAPESP). This work was supported by grants from Fundação de Amparo à Pesquisa do Estado de São Paulo (FAPESP), Conselho Nacional de Desenvolvimento Científico e Tecnológico (CNPq), and Fundação para o Desenvolvimento da UNESP (FUNDUNESP).

\section{References}

Altschul SF, Gish W, Miller W, Myers EW and Lipman DJ (1990) Basic local alignment search tool. J Mol Biol 215:403-410.
Avise JC (1994) Molecular markers, natural history and evolution. Chapman \& Hall, London, 551 pp.

Bielawski JP and Pumo DE (1997) Randomly amplified polymorphic DNA (RAPD) analysis of Atlantic Coast striped bass. Heredity 78:32-40.

Billington N, Barrette RJ and Hebert PDN (1992) Management implications of mitochondrial DNA variation in walleye stocks. North Am J Fish Manag 12:276-284.

Brzuzan P (2000) Tandemly repeated sequences in mtDNA control region of whitefish, Coregonus lavaretus. Genome 43:584-587.

Géry J (1977) Characoids of the world. T.F.H. Publications, Neptune City, 672 pp.

Grewe PM and Hebert PDN (1988) Mitochondrial DNA diversity among broodstocks of the lake trout, Salvelinus namaycush. Can J Fish Aquat Sci 45:2114-2122.

Iguchi K, Watanabe K and Nishida M (1999) Reduced mitochondrial DNA variation in hatchery populations of ayu (Plecoglossus altivelis) cultured for multiple generations. Aquaculture 178:235-243.

Kimura M (1980) A simple method for estimating evolutionary rate of base substitution through comparative studies of nucleotide sequences. J Mol Evol 16: 111-120.

Koh TL, Khoo G, Fan LQ and Phang VPE (1999) Genetic diversity among wild forms and cultivated varieties of Discus (Symphysodon ssp.) as revealed by random amplified polymorphic DNA (RAPD) fingerprinting. Aquaculture 173:485-497.

Lee WJ, Conroy J, Howell WH and Kocher TD (1995) Structure and evolution of teleost mitochondrial control regions. J Mol Evol 41:54-66.

Nesbo CL, Fossheim T, Vollestad LA and Jakobsen KS (1999) Genetic divergence and phylogeographic relationships among European perch (Perca fluviatilis) populations reflect glacial refugia and postglacial colonization. Mol Ecol 8:1387-1404.

Nielsen JL, Gan CA, Wright JM, Morris DB and Thomas K (1995) Biogeographic distributions of mitochondrial and nuclear markers for southern steelhead. Mol Mar Biol Biotech 3:281-293.

Perez-Enriquez R, Takagi M and Taniguchi N (1999) Genetic variability and pedigree tracing of a hatchery-reared stock of red sea bream (Pagrus major) used for stock enhancement, based on microsatellite DNA markers. Aquaculture 173:413-423. 
Quattro JM and Vrijenhoek RC (1989) Fitness differences among remnant populations of endangered Sonoran topminnow. Science 245:976-978.

Reilly A, Elliott NG, Grewe PM, Clabby C, Powell R and Ward RD (1999) Genetic differentiation between Tasmanian cultured Atlantic salmon (Salmo salar L.) and their ancestral Canadian population: comparison of microsatellite DNA and allozyme and mitochondrial DNA variation. Aquaculture 173:459-469.

Rozas J and Rozas R (1999) DnaSP version 3: an integrated program for molecular population genetics and molecular evolution analysis. Bioinformatics 15:174-175.

Saccone C, Lanave C, Pesole G and Sbisà E (1993) Peculiar features and evolution of mitochondrial genome in mammals. In: DiMauro S and Wallace DC (eds) Mitochondrial DNA in human pathology. Raven Press, New York, NY.

Sambrook J and Russell DW (2001) Molecular cloning: a laboratory manual. Cold Spring Harbor Laboratory Press. Cold Spring Harbor, New York.

Sbisà E, Tanzariello F, Reyes A, Pesole G and Saccone C (1997) Mammalian mitochondrial D-loop region structural analysis: identification of new conserved sequences and their functional and evolutionary implications. Gene 205:125140.

Shedlock AM, Parker JD, Crispin DA, Pietsch TW and Burmer GC (1992) Evolution of the salmonid mitochondrial control region. Mol Phylogenet Evol 1:179-192.

Sivasundar A, Bermingham E and Orti G (2001) Population structure and biogeography of migratory freshwater fishes (Prochilodus: Characiformes) in major South American rivers. Mol Ecol 10:407-417.

Thompson JD, Higgins DG and Gibson TJ (1994) Clustal W: improving the sensitivity of progressive multiple sequence alignment through sequence weighting, position-specific gap penalties and weight matrix choice. Nucleic Acids Res 22:4673-4680.

Was A and Wenne R (2002) Genetic differentiation in hatchery and wild sea trout (Salmo trutta) in the Southern Baltic at microsatellite loci. Aquaculture 204:493-506.

Yoon JM and Park HY (2002) Genetic similarity in the cultured and wild Crucian carp (Carassius carassius) estimated with random amplified polymorphic DNA. Asian-Australasian J Animal Sci 15:470-476

Associate Editor: Yatiyo Yonenaga-Yassuda 